\title{
THE EXPERIMENTAL TESTING OF BLENDED LEARNING METHODS OF ORAL JAPANESE LANUAGE TEACHING AIMED AT FUTURE PHILOLOGISTS
}

\author{
O. Asadchykh, T. Dybska
}

У дослідженні описуються сутнісні характеристики експериментального впровадження методики змішаного навчання усного японського мовлення майбутніх філологів, а також обтрунтовано адекватність методу експерименту для перевірки гіпотези дослідження. Зазначено особливості організації методичного експерименту, який мав на меті виявити, наскільки ефективними для навчання усного японського мовлення є обрані чотири основні моделі: «Face-to-Face Driver», щзо застосовувалася на заняттях зі студентами першого року навчання, «модель почергового розподілу форм роботи» для студентів другого року навчання, «модель зміни робочих зон» для майбутніх філологів третього року навчання $i$ «модель перевернутоі аудиторії», щз використовувалася на четвертому курсі освітнього рівня «бакалавр»; а також три допоміжні моделі: «Flex» для роботи із студентами, щзо знаходяться на індивідуальному графіку або вимушені наздогнати певний матеріал, "Online Lab» для дистанційного навчання за особливих передумов $і$ потреб курсу, а також «Self-Blend» для організачії самостійної роботи студентів над додатковими курсами на етапі незалежного користувача. Експеримент тривав два роки і проводився на всіх уеагах освітнього рівня «бакалавр» від першого до четвертого. У статті висвітлено організаційні і змістові аспекти експериментального навчання студентів із використанням верифікаційних можливостей експерименту в дослідницькій практиці формування усного японського мовлення у майбутніх філологів. Зазначаються також два варіанти авторської методики, щуо відрізняються між собою наявністю або відсутністю елементів мікронавчання (мікропошуку) під час очних занять, з яких перевагу було надано другому. В результаті експерименту було доведено, щуо обидва з ици варіантів методики показали себе як успішні, хоча наявність мікропошуку і не вплинула на рівень сформованості компетентностей в аудіюванні, монологічному та діалогічному мовленні

Ключові слова: моделі змішаного навчання, проведення експерименту, критерії оцінювання усного японського мовлення

Copyright (C) 2020, O. Asadchykh, T. Dybska. This is an open access article under the CC BY license (http://creativecommons.org/licenses/by/4.0).

\section{Introduction}

Creation of multidimensional contacts between Japan and Ukraine during the last twenty eight years indicates the need in training highly qualified specialists in the sphere of japanistics (philologists and translators), able to provide communication that service different directions of double-side relations at the high level.

Today in Ukraine twelve higher educational institutions prepare specialists in Japanese language. And there are essential achievements in the theory and practice of teaching it.

But existing works not at all cover all problems of Japanese teaching methods. Today Japanese linguodidactics needs substantial studies, elaboration and probation of new teaching methods, because Japanese typologically differs from Ukrainian and German languages (learnt by students just at school), and the culture of non-verbal behavior of Japanese people has practically no analogues in the world. It creates a series of additional complications of lingual, extralingual and paralingual type at studying Japanese, and also needs searching for new ways of optimization of the studying process, use of new informational and educational resources.

\section{Literary review}

Separate aspects of teaching Japanese became a research object by O. Asadchykh (teaching of Japanese academic speech of future philologists) [1], V. Holubets (teaching of Japanese grammar) [2], M. Arakava (methodical competence formation in teaching Japanese reading for senior students of pedagogical HEI) [3], N. Radzorska (teaching Japanese for international relations students, based on socio-political texts) [4], K. Avdeeva (use of comic books at teaching Japanese for students of the second year of a linguistic HEI) [5], $\mathrm{N}$. Ivanova (culturological approach to teaching Japanese as a second foreign language for students of linguistic HEI) [6], O. Grunina (method of formation of the translation and informational-analytic competence in students in the process of studying Japanese, taking into account the national-cultural specificity of language carriers) [7].

Taking into account a significant interest of the scientific community to language teaching problems, let's ascertain that the problem of studying the complex method of blended learning of oral Japanese language at higher school has not been considered yet. At the same time teaching of oral Japanese language in Ukraine is realizing without taking into account conditions of a concrete academic environment, without program orderliness of courses, is often a business of teachersenthusiasts now. So, there is a long-term need to systematize the teaching process of oral Japanese language and also to introduce the method of blended learning into the educational process of HEI. 


\section{Aim and tasks of the research}

The aim of the stu is to verify experimentally the effectiveness of the method of blended learning of oral Japanese language, aimed at future philologists.

To achieve the aim, the following tasks were set:

1) to make a review of the experimental teaching organization;

2) to formulate evaluation criteria for the competence in listening and speaking of future philologists;

3 ) to present experimental results.

\section{Organization of the methodical experiment}

For confirming the quality and effectiveness of the elaborated method of blended learning of oral Japanese language, aimed at future philologists, the experimental teaching was conducted.

The organization and conduction of the experiment were grounded on determined aim, tasks, object and subject of the research, time limitation, distinct plan, determined hypothesis, varied value, possibility of isolated inclusion of a methodical impact of the studied factor; on elaborated criteria and standards for evaluating control objects (qualitatively and quantitatively measured); on using mathematical statistics methods for calculating experimental results and verifying the research hypothesis.

The aim of the experiment is in verifying the effectiveness of the method of blended learning of oral Japanese language, aimed at future philologists, realized in four main models («Face-to-Face Driver», «Activities rotation model», «Working space rotation model», «Flipped classroom model») and three additional ones («Flex», «Online Lab» and «Self-Blend»), using the elaborated subsystem of activities and tasks.

According to the set aim, there were determined experimental tasks:

1) to conduct a pre-experimental section among 2,3 and 4-year students for revealing a formation level of competences in Japanese speaking and listening in them;

2) to prepare learning materials according to each model of blended learning, to distribute them between stationary and distant working forms and also to place a part of materials for distant learning at the platform Google Classroom, Youtube, Kahoot! and Memrise, to elaborate evaluation criteria and norms;

3) to plan the course of the experiment; to select its participants;

4) to conduct the experimental teaching in the experimental groups, having implemented two variants of the method according to the varied condition of the experiment;

5) to conduct total (post-experimental) sections for revealing a formation level of competences in Japanese speaking and listening in students; to analyze the obtained results, using methods of mathematical statistics;

6) to formulate methodical preconditions of the effectiveness of the method of blended learning of oral Japanese language, aimed at future philologists.

The research object at the experiment is the teaching process of oral Japanese language, aimed at future philologists.

The research subject at the experiment is formed competences of oral Japanese language of future philolo- gists - competence in listening and speaking (monologic, dialogic).

The experiment duration was determined by us according to the elaborated teaching models. The experiment lasted for 2 years, students of 1-4 years were engaged. At the first year the experiment duration was 320 hours, among which a share of classroom activities was 160 hours, and outclass - 160 hours. At the second year the experiment lasted for 192 hours (96 hours of classroom activities and 96 hours of independent work), at the third year - 128 hours (64 of classroom and 64 of outclass activities), and at the fourth year - 64 hours ( 32 hours of classroom activities and 32 hours of independent work).

The experiment hypothesis. The analysis of theoretical works on methods of teaching foreign languages, determined theoretical principles of blended learning of oral Japanese language, aimed at future philologists, gave a possibility to formulate a hypothesis: the effectiveness of the method of blended learning of oral Japanese language, aimed at future philologists is high under conditions of: system use of practices of stationary, distant, online and interactive teaching; organization of teaching on the principles of communicative, competence, linguoethnographic, personally oriented approaches; use and distribution of selected materials; use of main models in the succession "Face-to-Face Driver» (at the first year of EL «bachelor») $\rightarrow$ «Activities rotation model» (at the second year of EL «bachelor») $\rightarrow$ «Working space rotation model» (at the third level of EL «bachelor») $\rightarrow$ «Flipped classroom model» (at the fourth year of EL «bachelor»), and also auxiliary models «Flex», «Online Lab», «Self-Blend», realized within correspondent systems of activities and tasks; use of variant B of the author's method.

According to the model of the author's method, the varied value determined the use/non-use of microlearning elements at class work.

Variant A is based on the fact that at carrying out class tasks students didn't use micro-learning elements (microsearch), but used only materials, offered by a teacher.

Variant B is based on the fact that at carrying out class tasks students used micro-learning elements (microsearch) without limitations.

The variant $B$ of the author's method was preferred because of described advantages of microsearch, consisted of immediate solutions of problems of the lingual, extralingual and paralingual type, appeared at carrying out exercises and tasks.

Unvaried conditions: quantitative composition of participants of the experiment in the experimental groups; equal initial level of students in both EG in the parallel in the speaking and listening competences; learning duration; selected learning materials, blended learning models and their succession, subsystem of exercises, evaluation criteria, experimenter.

Selection of experiment participants. Taking into account the fact that the number of students in 1 academic group of Japanese is near 10 persons, and such sample may influence the results' reliability, we have formed $\mathrm{EG}_{1}$ - groups, studied during 2016-2017 by the model A of the author's method ( $\mathrm{EG}_{1} 1$ (I year), $\mathrm{EG}_{1} 2$ 
(2 year), $\mathrm{EG}_{1} 3$ (3 year), $\mathrm{EG}_{1} 4$ (4 year),). And also $\mathrm{EG}_{2}-$ groups, studied during 2018-2019 by the model B of the author's method ( $\mathrm{EG}_{2} 1$ (I year), $\mathrm{EG}_{2} 2$ (2 year), $\mathrm{EG}_{2} 3$ (3 year), $\mathrm{EG}_{2} 4$ (4 year),).

The experiment included students of $\mathrm{EG}_{1} 1$ (21 persons), $\mathrm{EG}_{1} 2$ (19 persons), $\mathrm{EG}_{1} 3$ (20 persons), $\mathrm{EG}_{1} 4$ (18 persons). ( $\mathrm{EG}_{2} 1$ (21 persons), $\mathrm{EG}_{2} 2$ (21 persons), $\mathrm{EG}_{2} 3$ (19 persons), $\mathrm{EG}_{2} 4$ (20 persons) of the specialty 0.35 . Philology (educational program: Japanese language, literature and translation, English language) of Kyiv national university, named after Taras Shevchenko. The total sample was used for determining participants of the experiment.

According to the classification of P.B. Gurvich [8], the described experiment was: basic, verticalhorizontal, natural, open.

Evaluation criteria of the listening competence

Today most scientists rely on the criterion of attaining the communicative aim that is in levels of text understanding at evaluating listening:

1) global understanding of an audio-text (characterized by such indicator: understanding of the main content of a message, based on understanding of the meaning of keywords);

2) detail understanding (characterized by indicator: understanding of language elements and details of the fact content of a message);

3) critical understanding of an audio-message (indicators: complete, deep and distinct understanding of the content of a message, its critical comprehension) [9].

Critical understanding includes the ability to understand a communicative intent of a speaker [10], and also to interpret a non-verbal behavior of speakers.

Thus, let's offer an evaluation scale:

Global understanding, we find expedient to control it by a test, realized by students after listening an audio-text (or several little texts). A text contains 10 questions. A student gets 1 point for each correct answer (totally - 10 points).

Detail understanding is controlled the same, using a test of 10 questions, realized by students after listening an audio-text. A student gets 1 point for each correct answer (totally - 10 points).

Critical understanding is evaluated by 10 points: 2 points for each correctly done test task of 5 test questions, related to understanding of an author's intention, emotional-evaluating information, implicit information, non-verbal behavior.

So, a student can get maximum 30 points for listening. Accordingly, 27-30 points is an index of the high education level, 23-26 points - an index of the enough educational level, 15-22 - an index of the satisfactory level, 14 and less points - an unsatisfactory index.

Evaluation criteria of the speaking competence

For evaluating the speaking competence, let's choose the criteria, offered by T. Druzhchenko [11] and L. Krysak [12], presented in detail below in Table 1.

Let's add to these criteria also one of adequate use of non-verbal communication means.

Speaking ease is characterized by "evenness, fast reaction to a stimulus, fluency, expressiveness, emotionality, absence of stammering and non-motivated pauses; selection of a vocabulary and construction of grammati- cal models are automatic". Communicative intent realization degree (communicative task realization: speaker's ability to realize a communicative intent (to inform, to describe, to ground, to contest an idea, the ability to initiate, to support, to finish a conversation). It is characterized by the fullness of content, distinct logical finish of an expression, observance of a topic. Informativeness provides the presence of new actual information, taken from reliable sources that enrich the listeners' worldview, first of all, their knowledge about the culture and customs of Japanese. The criterion of speaking literacy provides observance of phonetic, linguistic, lexical and grammatical standards of the Japanese language. [11]. Interactivity is determined by the ability to put questions, to answer them in detail, to motivate a collocutor to a dialogue, to react to an offer and also by adequacy and correspondence of cues to collocutor's ones [12].

Table 1

Evaluation criteria of monologue and dialogue

\begin{tabular}{|c|c|}
\hline $\begin{array}{c}\begin{array}{c}\text { Evaluation criteria of } \\
\text { monologue }\end{array} \\
\end{array}$ & $\begin{array}{c}\begin{array}{c}\text { Evaluation criteria of } \\
\text { dialogue }\end{array} \\
\end{array}$ \\
\hline \multicolumn{2}{|c|}{ speaking ease } \\
\hline informativeness & interactivity \\
\hline \multicolumn{2}{|c|}{$\begin{array}{l}\text { Communication intent realization degree (realization } \\
\text { of a communication task) }\end{array}$} \\
\hline Speakir & eracy \\
\hline
\end{tabular}

The criterion of adequacy of using non-verbal communication means provides the use of non-verbal behavior means in oral communication that corresponds to standards of language carriers, is perceived adequately by them.

We develop 3-point evaluation scale by each criterion (by T. Druzhchenko) [11]), according to which a student gets 3 points, if his/her speaking maximally corresponds to the criterion, 2 points - if unessential mistakes that don't result in a failure of communication are present, 1 point - mistakes are significant, misunderstanding of total information blocks by an collocutor appears.

The experiment, devoted to controlling the effectiveness of the method of blended learning of oral Japanese language, aimed at future philologists, consisted of the pre-experimental section, experimental teaching, intermediate section and post-experimental one.

The pre-experimental section lasted for 4 hours and provided revelation of the existent formation level of competences in listening, monologic and dialogic speech in students-philologists of II, III and IV years.

At the following stage of our study there was the experimental teaching, conducted by two variants of the author's method:

Variant $\mathbf{A}$ is based on the fact that at carrying out class tasks students didn't use micro-learning elements (microsearch), but used only materials, offered by a teacher.

Variant B is based on the fact that at carrying out class tasks students used micro-learning elements (microsearch) without limitations.

In the groups $\mathrm{EG}_{1} 1$ (I year), $\mathrm{EG}_{1} 2$ (2 year), $\mathrm{EG}_{1} 3$ (3 year), $\mathrm{EG}_{1} 4$ (4 year) the experimental teaching was conducted during 2017-2018 academic year. In the groups $\mathrm{EG}_{2} 1$ (I year), $\mathrm{EG}_{2} 2$ (2 year), $\mathrm{EG}_{2} 3$ (3 year), $\mathrm{EG}_{2} 4$ (4 year) the experimental teaching was conducted during 2018-2019 academic year. 
After 1th semester, the intermediate section was conducted for establishing the positive dynamics in Japanese oral speaking competences formation of future philologists.

For that the students were offered tasks, analogous to ones of the pre-experimental tasks.

The post-experimental section was conducted after the experimental teaching. There were elaborated tasks, analogous to the ones of the preexperimental and intermediate sections, for the postexperimental one.

\section{Research results}

So, we have experimentally proved, that the effectiveness of the method of blended learning of oral Japanese language, aimed at future philologists is high under conditions of: system use of practices of stationary, distant, online and interactive teaching; organization of teaching on the principles of communicative, competence, linguo-ethnographic, personally oriented approaches; use and distribution of selected materials; use of main models in the succession "Face-to-Face Driver»" «Activities rotation model» $\rightarrow$ «Working space rotation model» $\rightarrow$ «Flipped classroom model» and also auxiliary models «Flex», «Online Lab», «Self-Blend», realized within correspondent systems of activities and tasks; use both variants of the author's method (both with microsearch or without it).

\section{Conclusions}

Let's summarize the obtained results according to the research aim.

1) The experiment lasted for 2 years, students of 1-4 years were engaged. At the first year the experiment duration was 320 hours, among which a share of classroom activities was 160 hours, and outclass -160 hours. At the second year the experiment lasted for 192 hours (96 hours of classroom activities and 96 hours of independent work), at the third year - 128 hours (64 of classroom and 64 of outclass activities), and at the fourth year - 64 hours (32 hours of classroom activities and 32 hours of independent work).

2) There have been formulated the evaluation criteria of competences in listening and speaking of future philologists, namely: a) adequacy of using non-verbal communication means; b) speaking ease; c) communicative intent realization degree; d) informativeness; e) speaking literacy; f) interactivity.

3) By comparing the results of the experimental teaching by the author's methods A and B, it has been revealed, that in the experimental groups, where the variant B of the author's method was used (that is microsearch), the formation level of competences in listening, monologic and dialogic speech didn't differ from the level of the experimental groups, where the variant A was applied. So, the experimental hypothesis has been partially confirmed.

\section{References}

1. Asadchykh O. V., Filonova V. O. Osnovy metodyky navchannia usnoho yaponskoho monolohichnoho movlennia na pochatkovomu rivni u vyshchii shkoli. Kyiv: Vydavnychyi dim Dmytra Buraho, 2018. 156 p.

2. Holubets V. V. Vykorystannia testovykh zavdan dlia navchannia studentiv movnykh spetsialnostei hramatychno pravylnoho yaponskoho movlennia: $\mathrm{PhD}$ thesis. Kyiv, 2003. 252 p.

3. Arakava M. V. Formirovanie metodicheskoi kompetencii v obuchenii chteniyu na yaponskom yazyke u studentov starshih kursov pedagogicheskih vuzov: yaponskii yazyk kak vtoroi inostrannyi: abstract PhD thesis. Saint Petersburg, 2007. 24 p.

4. Razdorskaya N. V. Osobennosti obucheniya yaponskomu yazyku studentov-mezhdunarodnikov na osnove obshchestvenno-politicheskih tekstov: abstract PhD thesis. Moscow, 2007. 29 p.

5. Avdeeva E. S. Ispol'zovanie komiksov pri obuchenii yaponskomu yazyku studentov vtorogo kursa yazykovogo vuza: abstract PhD thesis. Moscow, 2009. 26 p.

6. Ivanova N. S. Kul'turovedcheskii podhod k obucheniyu studentov yazykovogo vuza yaponskomu yazyku kak vtoromu inostrannomu: abstract PhD thesis. Saint Petersburg, 2007. 26 p.

7. Grunina O. N. Metodika formirovaniya perevodcheskoi i informacionno-analiticheskoi kompetencii studentov v processe obucheniya yaponskomu yazyku s uchetom nacional'no-kul'turnoi specifiki nositelei yazyka: abstract PhD thesis. Moscow, 2012. 25 p.

8. Gurvich P. B. Teoriya i praktika eksperimenta v metodike prepodavaniya inostrannyh yazykov: speckurs. Vladimir: Izdatel'stvo Vladimirskogo pedagogicheskogo instituta im. P. I. Lebedeva-Polyanskogo, 1980. 104 p.

9. Zabolotna M. I. Metodyka navchannia audiiuvannia anhlomovnykh publitsystychnykh tekstiv starshoklasnykiv v umovakh profilnoho navchannia: $\mathrm{PhD}$ thesis. Kyiv, 2014. $255 \mathrm{p}$.

10. Fedorova O. A. Formuvannia audytyvnykh umin inozemnykh slukhachiv pidhotovchoho viddilennia u protsesi navchannia ukrainskoi movy: $\mathrm{PhD}$ thesis. Ivano-Frankivsk, 2016. $260 \mathrm{p}$.

11. Druzhchenko T. P. Metodyka dyferentsiiovanoho navchannia anhliiskoho usnoho monolohichnoho movlennia maibutnikh yurystiv: PhD thesis. Kyiv, 2018. 268 p.

12. Krysak L. V. Metodyka navchannia maibutnikh likariv zahalnoi praktyky anhlomovnoho profesiino oriientovanoho dialohichnoho movlennia: $\mathrm{PhD}$ thesis. Kyiv, 2016. 288 p.

Received date 28.01.2020

Accepted date 14.02.2020

Published date 25.05.2020

Oksana Asadchih, Doctor of Science in Pedagogical Studies, Professor, Department of Far East and Southeast Asia Languages and Literature in The Institute of Philology, Taras Shevchenko National University of Kyiv, Volodymyrska str., 60, Kyiv, Ukraine, 01033

Tetiana Dybska, Department of Far East and Southeast Asia Languages and Literature in The Institute of Philology, Taras Shevchenko National University of Kyiv, Volodymyrska str., 60, Kyiv, Ukraine, 01033

E-mail: whirlwhite@gmail.com 